\title{
French at odds on new law
}

The law to regulate French universities has been signed - and opposing interests are already battling for influence over the decrees that will follow

EXCEPT for a little trouble with the French constitution, which should be resolved next month, France now has a new university law, the first major revision of university law since the student revolution of May 1968. But is the reform too little? Has a great opportunity been lost? The vociferous critics of the new law, notable among them Fields Medallist Laurent Schwartz of the Ecole Polytechnique, say loudly that it has been. Strangely enough, Schwartz's opponent at the ministry of education is another mathematician of similar intellectual temperament: Jean-Jacques Payan, ex-director-general of the principal French research council (CNRS) and ex-president of the University of Grenoble I, one of the foremost scientific universities of France. If Schwartz says the government has fumbled its chance, the man responsible is Payan. But Payan does not think he fumbled the ball but, instead, that he has made a pretty clever pass.

The differences between the two men, which epitomize the arguments over the future of the French university, are based less on differences of outlook than on differences of responsibility. Schwartz is a free spirit, outside the universities and with no power to exercise nor political pressure to which to adjust. Payan is in the hottest seat of all, in charge of the reform and acutely aware of what can and cannot be achieved. The new law is pragmatic, he admits, "but it proscribes little and permits much". Payan urges France to wait for the detailed, nonparliamentary "decree of application" which follows every law. Here may be some of the teeth, some of the support for research that Schwartz demands. "I have the same passion [as Schwartz]: the greatness of the French university", wrote Payan recently. So well do these conflicting passions set each other off than one must wonder whether Schwartz and Payan are in league, one creating the political climate that the other needs.

In reality, there are fundamental differences between the two men and the bodies of opinion they represent. Schwartz and those he speaks for wish to reintroduce selection in the first-year entry to university, the absence of which creates a "catastrophe" for both students and teachers. Payan and the law he represents avoid pre-entry selection and speak of post-entry "evaluation". Entry to the second and subsequent years will, in effect, be selective (as at present) but the word "evaluation" implies more: the universities should not evaluate the students according to some predetermined scheme but according to their students' needs, says Payan. Thus by implication in the new laws, the universities are to turn their resources towards their students, rather than the other way about. This is a revolution: it implies that the universities must become, at least in part, more like the existing technical institutes (IUT) or engineering schools (grandes écoles), for the students of the 1980 s will certainly demand training that will lead to employment.

What of the dominance of French universities by trade unions and "corporatism"? Elections to various powerful committees of administration and promotion play a great - some say overwhelming - role in the post-1968 French university, and often these elections have been dominated by factional politics, with one union or body of staff against another. Schwartz says the new law worsens the situation. Payan, with some force, argues the reverse and, since he is no syndicalist, the benefit of the doubt must rest with him. According to Payan, the fact that under the new law elections will be by proportional representation, with freedom for non-ascribed candidates, rather than the earlier winner-takes-all system, means that corporatism will be much diminished.

And what of research? Is it ignored by the law, as Schwartz says? Wait for the decree that will define the duties of university lecturers and professors, says Payan. Meanwhile, the text of the law introduces a sabbatical year - a welcome innovation for French scientists. It also establishes periodic evaluation of staff to keep them up to scratch, new recruitment procedures that "will leave little room for the establishment of local cliques" and imposes an obligation of mobility on professors. All this will improve the quality of French university research, says Payan. Moreover, the ministry is turning to a system of research support by multi-annual contracts, rather than the annual support related directly to student numbers presently in force. This should give the universities, traditionally dominated by central government, more academic independence.

As for the decree defining duties, that has been through many drafts and tense negotiations with the unions, and is now again being rewritten. The ministry says that it will take research "much more into account" than previous versions, meeting criticism from the presidents of the universities and others. Payan's early insistence on increased teaching duties and a longer working year will be somewhat softened and the duties are now being seen to be an overall requirement on a university, to be distributed according to some as yet undefined rules. The heavier teaching load will not be a direct requirement on individuals. The result of this, however, in conjunction with the law's insistence on free entry and on the evaluation of student need, may be to create a two-tier university structure in France. Some will teach, others will do research.

The pattern of research will also be transformed by the proposed change in the structure of higher degrees. The old troisième cycle, and the thèsed'etat, respectively lesser versions of the $\mathrm{PhD}$ and DSc (the latter taking eight or nine years) are to be abandoned in favour of something approaching a PhD. This, most French scientists consider, will bring French science in to line with the United States and Britain. But the new law has shrunk from out-and-out advocacy of meritocracy. As things are, wouldbe researchers can edge their way into laboratories on private means and eventually obtain a permanent post by waiting long enough, rather as in Italy. This system will continue even under the new law unless a comprehensive system of competitive grants is introduced. That step, still neglected, would do more than anything else to better the condition of science in France.

\section{Ivory tower in space? \\ $N A S A$ should be restrained from mounting $a$ crash programme to build a US space station}

THE National Aeronautics and Space Administration (NASA), set up in the heady days of the early 1960s, has always thrived on large engineering projects, undertaken on a crash basis with billions of dollars to throw about. Now that NASA has declared the shuttle operational (which, given recurring problems, including an explosion and fire after the shuttle's most recent 